\title{
In Memoriam: Professor Hugh W. A. Thirlway (14 June 1937 - 13 October 2019)
}

\author{
Cristina Hoss ${ }^{1}$, Santiago Villalpando ${ }^{2}$ and Eric De Brabandere ${ }^{3 *}$ \\ ${ }^{1}$ International Court of Justice, Carnegieplein 2, 2517 KJ The Hague, Netherlands, Email: c.hoss@icj-cij.org, ${ }^{2}$ United Nations \\ Educational, Scientific and Cultural Organization (UNESCO), Email: s.villalpando@unesco.org and ${ }^{3}$ Leiden University, \\ Grotius Centre for Intern Legal Studies, Turfmarkt 99, 2511 DP The Hague, Netherlands, Email: e.de.brabandere@law. \\ leidenuniv.nl
}

The finest 'unseen actor' ${ }^{\text {' }}$ all has left the stage. It is with great sadness that we learned that Hugh Thirlway - former Principal Legal Secretary of the International Court of Justice, Professor of International Law and good friend of the Leiden Journal - passed away on 13 October 2019. A few weeks earlier, after completing yet another of his countless scholarly writings, he had announced that he anticipated this would be his last publication. ${ }^{2}$ At the time, we were in disbelief: Hugh not writing was something hardly conceivable ... In a way, it still is.

For anyone who has read Hugh's light, elegant and witty drafting-style, this tribute is bound to appear clumsy and perhaps ungainly. We do hope that Hugh would nonetheless have recognized himself - or, à défaut, that he would have approved of the picture that we are about to draw of him.

Hugh Thirlway was born in Ealing (London) in 1937. He went to St. John's College, Cambridge, on an Open Scholarship and State Scholarship from 1955 to 1959. He began by reading Classics, switching to Law after the first year. In 1961, he was awarded his MA degree, joining a respected law firm in the same city as a solicitor, mainly handling tax law matters for the University. For reasons unknown to us, he took sabbatical leave from the law firm and moved to France, where he enrolled at the University of Nancy in the Licence of Private Law. This is where he would later complete a $\mathrm{PhD}$ in Private International Law ... en français! $!^{3}$

Hugh described his beginnings in public international law as a case of good timing and good fortune. His professional activity as a solicitor in Cambridge and his specialization in private

\footnotetext{
${ }^{\star}$ Cristina Hoss is a Legal Officer (Secretary of the Court) at the International Court of Justice and Visiting Professor at the Université Catholique de Lille; Santiago Villalpando is the Legal Adviser and Director of the Office of International Standards and Legal Affairs at the United Nations Educational, Scientific and Cultural Organization (UNESCO); Eric De Brabandere is Editor-in-Chief of the Leiden Journal of International Law, Professor of International Dispute Settlement Law and Director of the Grotius Centre for International Legal Studies at Leiden University Law School. The ideas and opinions expressed herein are those of the authors and do not necessarily represent the views of UNESCO or the International Court of Justice. The authors would like to thank Elisabeth Jordan for her comments on the first draft.

${ }^{1}$ See H. Thirlway, 'Foreword', in F. Baetens (ed.), The Legitimacy of Unseen Actors in International Adjudication (2019), at xix-xxiii.

${ }^{2}$ H. Thirlway, 'The Significance of Procedure in the Judicial Settlement of International Disputes', in J. Gomula and S. Wittich (eds.), Research Handbook on International Procedural Law (forthcoming).

${ }^{3}$ See Thirlway, La reconnaissance et l'exécution réciproques des jugements en matière patrimoniale, dans les rapports entre la Grande-Bretagne et les pays du marché commun (1969), at 2 (Thèse polycopiée, soutenue le 27 juin 1969, Université de Nancy, devant Professeur Paul Lagarde, Professeur Denis Tallon, Mme Hélène Gaudemet-Tallon [Maitre de conférence] and M. Phocion Franceskakis, Directeur de Recherche au CNRS). Even though Thirlway himself underlines the public law origins of the law of execution of foreign judgments in his thesis, he accepted the classification of his $\mathrm{PhD}$ thesis as pertaining to private international law.
} 
international law did not necessarily point to a future career in public international law, let alone at the principal judicial organ of the United Nations. He himself candidly admitted that he did not quite know what he was getting into at the time when he applied to the International Court of Justice for the vacant post of 'Secretary of the Court', ${ }^{4}$ but he had been attracted by the opportunity to work in the field of international law. He passed the tests haut la main, including translation and interpretation, and was offered the position, which he accepted enthusiastically, immediately starting house-hunting and looking for suitable schools for his, then two, children. ${ }^{5}$

In addition to his career as a civil servant, Hugh will also - and perhaps to the Leiden Journal's readership mostly - be remembered for his scholarship and activity as a scholar. Alongside and inbetween his functions at the Court, he held positions as Professor of International Law (1994-2000) and Visiting Professor (2001) at the Graduate Institute of International Studies in Geneva, Fellow at Wolfson College and the Lauterpacht Centre for International Law in Cambridge (1999-2000), Honorary Visiting Fellow at Leiden University (Meijers Fellow 2000-2001), Visiting Professor at the University of Bristol (2001-2003 and 2009-2014), Visiting Professor at the East China Normal University in Shanghai (2002), and Visiting Professor at Leiden University Law School (2007-2015). 'In recognition of his distinguished career and continual support of the Centre', Hugh was appointed Honorary Fellow of the Lauterpacht Centre for International Law, thereby joining other renowned scholars and practitioners such as Sir Derek Bowett, Sir Christopher Greenwood, Dame Rosalyn Higgins, Hisashi Owada, and Stephen M. Schwebel. ${ }^{6}$

\section{The international civil servant}

Hugh Thirlway took up his first employment with the Court on 1 September $1968 .^{7}$ His position was somewhat different from what it would be nowadays. While the Registry has today some 100 officials and consists of three departments and a number of technical divisions, ${ }^{8}$ it was at that time a microcosm of only 28 staff members, all categories included. ${ }^{9}$ There were four First Secretaries of the Court, the most senior being in charge of information matters, and two Secretaries, ${ }^{10}$ the young Hugh being one of them. Given the small number of officials, their tasks in those days were considerably more diversified. They would be expected to carry out research and provide legal assistance to Members of the Court, serve as translators and interpreters, act as a channel of communication with states, and perform diplomatic tasks. Hugh recounted many times how much he enjoyed those early years of discovery at the Court ${ }^{11}$ and his work as translator and interpreter, professional specializations in which he had never actually qualified.

Within only four years, Hugh was promoted from the position of Secretary to that of First Secretary. ${ }^{12}$ He held that title for about 15 years, until a new position was created for him in

\footnotetext{
${ }^{4}$ Before taking up the position, he did, however, meet Lord McNair in Cambridge who told him about the workings of the Court. The meeting is briefly described in H. Thirlway, 'The Drafting of ICJ Decisions: Some Personal Recollections and Observations', (2006) 5 Chinese Journal of International Law 15, at 15.

${ }^{5}$ There were more to come.

${ }^{6}$ See Lauterpacht Centre for International Law, 'Annual Report 2013-2014', at 18, available at www.lcil.cam.ac.uk/files/ images/www.lcil.law.cam.ac.uk/Image/Publications/AR/lcil_annual_report_2013-2014.pdf.

${ }^{7}$ I.C.J. Yearbook 1968-1969, at 88.

${ }^{8}$ I.C.J. Yearbook 2016-2017, at 52

${ }^{9}$ I.C.J. Yearbook 1968-1969, at 88.

${ }^{10}$ Art. 43 of the Instructions for the Registry. In 1968-1969, the First Secretaries and Secretaries of the Court were, without exception, either British or French nationals.

${ }^{11}$ To one of us who once marvelled at the fact that he had witnessed the deliberations of the Barcelona Traction judgment and asked him whether at the time the concept of obligations erga omnes coined by the Court was perceived as a novel idea, Hugh Thirlway answered with a nostalgic smile: 'You know, at the time, everything at the Court was novel to me!'

${ }^{12}$ I.C.J. Yearbook 1971-1972, at 101.
} 
1987, that of Principal Legal Secretary of the Court. ${ }^{13}$ It was the Court's way of marking publicly its recognition of his invaluable role in the Registry. In the meantime, his functions had specialized, becoming the Director of the Department of Legal Matters of the Registry, in charge of all legal issues relating to the support of the Court's work.

His attachment to the institution was unrivalled; the fact that he retired three times from the Court indicates that the attachment was reciprocal. He resigned from the position of Principal Legal Secretary in 1994, when he took up his professorship at the Graduate Institute in Geneva. In 2003, he was called back and returned to the Court to resume his position, from which he retired again in 2005, ${ }^{14}$ before returning a third time in 2006. In 2008, Hugh retired for the third and last time from the Court. The Department of Legal Matters has since changed considerably, with 15 junior lawyers assisting the judges in their individual tasks. Somehow, his presence and legacy continue to be felt. Those of us who had the opportunity to work with Hugh still miss him enormously, wherever our career paths have taken us. At times, when faced with a delicate legal issue, we think: 'what would Hugh have done?', 'how would he have dealt with this legal conundrum?', 'how would he have turned this phrase?'. His intelligent and methodical approach to legal issues, his engagement, modesty and calmness, his company and willingness to share his immense experience will not be forgotten. For his junior staff, he was a patient, ever so subtle, teacher, nudging rather than instructing, and a rich source of countless anecdotes at occasional lunches in the Restaurant des Juges. And he would listen: he would take you by surprise in the midst of the consideration of a complex legal issue, asking what you thought about it and then carefully pondering your point of view. A rare, almost unique, quality in our profession.

As Principal Legal Secretary, he had special standing not only within the Registry but also with Members of the Court who knew that he was not only extraordinarily knowledgeable, but also loyal and trustworthy. Whenever consulted, he could speak with authority and would even be listened to. He saw his role as that of a devil's advocate, the advocatus diaboli, ${ }^{15}$ a technique he also employed in his academic writing, always thinking of ways to deconstruct an argument. Perhaps this was a way to entertain his 'never-ceasing restlessness of the mind', ${ }^{16}$ but he had no ulterior motive other than to ensure that the Court received the best possible assistance to make an informed decision.

\section{The Scholar}

To review fully Hugh's writings would be a task of such magnitude that we feel unable to even attempt to do so. His seminal 2,000-page work on the Law and Procedure of the International Court of Justice ${ }^{17}$ will, for a long time still, be the gold standard of legal scholarship in the field. He had taken it upon himself to continue the series published in the British Yearbook of International Law by Sir Gerald Fitzmaurice, whom he had much admired, and in 2013, at the request of Oxford University Press, published those articles in two volumes covering 50 years of the Court's jurisprudence. Thus, instead of providing readers with a full account of his writings, let us try to offer a few impressionist thoughts to recall his contribution to international legal scholarship and to pay tribute to Hugh Thirlway, the Scholar.

What first comes to mind are his remarkable drafting skills. His style, probably trained first at boarding school and then at Cambridge, and refined by many years at the Court, was of surgical precision; it was elegant and light, sober yet gripping, quite often supplemented by some witty

\footnotetext{
${ }^{13}$ I.C.J. Yearbook 1986-1987, at 111.

${ }^{14}$ As described in the first footnote of his article supra note 4, at 16.

${ }^{15}$ Ibid., at 17.

${ }^{16}$ An expression we borrow from Shabtai Rosenne's description of Hersch Lauterpacht. See S. Rosenne, 'Sir Hersch Lauterpacht's Concept of the Task of the International Judge', (1961) 55 American Journal of International Law 825, at 829.

${ }^{17} \mathrm{H}$. Thirlway, The Law and Procedure of the International Court of Justice: Fifty Years of Jurisprudence (2013).
} 
comment hidden in a footnote. ${ }^{18}$ Admittedly, Hugh's writings are not an easy read: they examine in vigilant detail the most technical aspects of the Court's work, and are replete with Latin and, at times, Greek ${ }^{19}$ references. Hugh indeed mastered the law and procedure of international dispute settlement perfectly, driven by an interest in the processes that lead to the making of judicial decisions and the functioning of international courts and tribunals. He had, one could say, more interest in the processes of dispute settlement than in their outcome, ${ }^{20}$ convinced that it is fundamental to know how a dispute is or can be settled, and how a decision comes into existence, in order to understand and fully grasp the contours of the end-product of the judicial processes.

His style and technical knowledge may make it somewhat harder for those new to our discipline to access Hugh's teachings. But for advanced students, practitioners, and scholars who are interested in the work of the Court (and are not terrified of ancient languages), Hugh's writings remain an indispensable tool towards a proper understanding of the Court's jurisprudence. One may add that, thanks to his outstanding linguistic skills, Hugh was able to do what any international lawyer ought to be capable of (and yet which seems beyond the grasp of so many current academics): ${ }^{21}$ he was able to refer to, and to reflect on, scholarship written not only in English, but in several other languages (in his case, French, German, Dutch, and Spanish).

His general approach is clearly spelled out in the concluding chapter of his prize-winning volume, International Law and Codification (1972): ${ }^{22}$ 'We must be on our guard against allowing the desirability of a given development to blind us to the obstacles it will have to overcome. ${ }^{23} \mathrm{He}$ stood by this approach throughout his very prolific time as a legal academic, reiterating his warning on several occasions. ${ }^{24}$

His views about international law could be misrepresented as being on the conservative end of the spectrum but they should actually be understood as being shaped by his practice and experience. Hugh was uniquely familiar with the internal working methods of the Court, with its collegial drafting and the weight given by those who draft judicial decisions to every single word, every formula, every colon. Therefore, he cared about precision and accuracy in scholarly writing, maybe more than other academics. In exceptional cases, he could be harsh in his criticism when finding that other authors had not examined and analysed the Court's decisions with the diligence that was, in his view, required. ${ }^{25}$ This was nothing personal. To him, it was a matter of intellectual integrity.

His insights made him wary of new fashionable 'theories' of international law, of new developments and of hastily written commentaries on the Court's jurisprudence. But it is to his credit that he would still take new scholarship seriously and engage with new doctrinal developments, as witnessed by the last chapter of his book The Sources of International Law. ${ }^{26} \mathrm{He}$ admitted having spent significant time and energy in trying to make sense of it all. In this exercise, he displayed intellectual honesty and open-mindedness but was rigorous in his assessment and, as an erudite avocatus diaboli, would dissect ideas and arguments with his usual flair.

\footnotetext{
${ }^{18} \mathrm{He}$ also had a taste for using semi-colons and (brackets).

${ }^{19}$ See H. Thirlway, 'The Role of Non-State Actors: A Response to Professor Ryngaert', (2017) 64 Netherlands International Law Review 141, at 153.

${ }^{20}$ See, amongst others, H. Thirlway, 'Territorial Disputes and Their Resolution in the Recent Jurisprudence of the International Court of Justice', (2018) 31(1) LJIL 117, at 146.

${ }^{21}$ See A. Roberts, Is International Law International? (2017), at 260-75.

${ }^{22} \mathrm{H}$. Thirlway, International Customary Law and Codification: An Examination of the Continuing Role of Custom in the Present Period of Codification of International Law (1972), at 146. Awarded the John Westlake Prize (1971) of the Institut de Droit International.

${ }^{23}$ Ibid., at 145 .

${ }^{24}$ E.g., H. Thirlway, 'Reflections on lex ferenda', (2001) 32 Netherlands Yearbook of International Law 3, at 26; H. Thirlway, The Sources of International Law (2019), at 146.

${ }^{25}$ By way of example see H. Thirlway, 'Dilemma or Chimera - Admissibility of illegally obtained evidence in international adjudication', (1984) 78 American Journal of International Law 622.

${ }^{26}$ See Thirlway, supra note $24,(2019)$ at $223-37$.
} 
For those international lawyers who had the opportunity to cross swords with him, he was a first-class sparring partner, using the foil rather than the sabre. He was never blasé or too tired to probe new scholarship and, if need be, to show its shortcomings. ${ }^{27}$ It was not only his perception of the 'incorrectness' or 'failures' of another's interpretations of the Court's decisions or scholarship that drove him. He thoroughly enjoyed engagement with other scholars, especially if he disagreed on certain issues. He felt the need to offer his own view and opinion on the subject, not out of personal satisfaction or credit, but for the 'greater good' of academic debate and diversity in views. One thus finds several of Hugh Thirlway's publications, including blog posts, which were drafted as explicit or implicit responses to writings either related to the Court ${ }^{28}$ or other subjects of interest. ${ }^{29}$ From this perspective, his approach to legal scholarship might be seen as being the essence of actual 'critical' legal scholarship.

For Hugh, it was a matter of intellectual integrity and honesty, but it must be added that he had the invaluable luxury of being in the relatively comfortable position of a legal practitioner who did not have to prove himself in the academic viper's nest. While being an international civil servant carries inevitable limitations in writing academic articles, Hugh's position as a legal practitioner made him free of academic constraints. He followed his own approach and did not feel the need for his writings to fit into, or be categorized as belonging to, a particular school of thinking. He could write without worrying about research grants and visibility, or download-statistics.

Hugh Thirlway's general approach to international law is illustrated by a few recurrent themes, which may be found in many of his writings and will hopefully inspire future generations. They are: his 'bête noire', the confusion between lex lata and lex ferenda; $;^{30}$ the sources of international law; ${ }^{31}$ any form of judicial activism $;^{32}$ and the warning against analogies from municipal law 'without taking sufficient account either of the degree of generality, actual or potential, of the municipal law rule, or of the accuracy of the analogy involved in its transfer to the international plane' ${ }^{33}$ To demands for more general dicta from the Court, he would respond: '[a] dispute is not an opportunity for a judge to set the world right on particular issues of international law; the Court's decisions are of course valued for their contribution to the development of international law; but that is not their primary function'. ${ }^{34}$ To calls for more transparency in international adjudication, he would reply: 'a case could be made for the view that transparency is not necessarily the highest value to be aimed at in international judicial settlement ... in this field there is something to be said for quieta non movere. ${ }^{35}$

In addition, Hugh never quite came to terms with the finding of the Court on the binding nature of provisional measures. At a conference held at the Max-Planck Institute in

\footnotetext{
${ }^{27}$ We could list a few references here but thought that this might be regarded as unkind and discourteous, something Hugh would not have approved of.

${ }^{28}$ By way of example see H. Thirlway, 'The Recommendations Made by the International Court of Justice: A Sceptical View', (2009) 58(1) International and Comparative Law Quarterly 151; H. Thirlway, 'EJIL Debate: A whale or a weasel? The Antarctic Whaling case, and a reply to Professor d'Aspremont (Parts I, II and a rejoinder)', EJILTalk!, 19 January 2018, available at www. ejiltalk.org/author/hughthirlway/.

${ }^{29}$ For example, see Thirlway, supra note 19.

${ }^{30} \mathrm{H}$. Thirlway, supra note 22 , at 145 .

${ }^{31}$ See Thirlway, supra note 24 (2019); H. Thirlway, 'Human Rights in Customary Law: An Attempt to Define Some of the Issues', (2015) 28(3) LJIL 495. Sources of international law was also the theme of his first specialized seminar, when he became Professor at the Graduate Institute in 1994.

${ }^{32}$ E.g., H. Thirlway, 'Peace, justice, and provisional measures', in G. Gaja and J. G. Stoutenburg (eds.), Enhancing the Rule of Law Through the International Court of Justice (2014), at 75-86; Thirlway, supra note 28 (2009); Thirlway, supra note 24 (2001); H. Thirlway, 'Judicial activism and the International Court of Justice', in N. Ando, E. McWhinney and R. Wolfrum (eds.) Liber amicorum Judge Shigeru Oda (2002), vol. 1, at 75-105.

${ }^{33}$ See Thirlway, supra note 25, at 622; H. Thirlway, 'Concepts, principles, rules and analogies: International and municipal legal reasoning', (2002) 294 RdC 265.

${ }^{34}$ See Thirlway, supra note 4 , at 23-4.

${ }^{35}$ See Thirlway, supra note 1 , at xxii.
} 
Heidelberg in 1993, in the years when doctrine was strongly favouring the binding nature of provisional measures, he had made a case against it in light of the Statute of the Court. ${ }^{36}$ For Hugh, provisional measures could only be binding as a matter of treaty law, namely the Statute to which states parties have agreed. His textual reading of the Statute, which he saw confirmed by his interpretation of the travaux préparatoires, militated against the binding nature of provisional measures. He also rejected the idea that provisional measures were 'decisions' referred to in Article 59 of the Statute and Article 94 of the Charter, with which states are required to comply. While acknowledging that an Order adopted by the Court was a 'decision', it was his firm conviction that the Court's 'decision' could only be to the effect that it would be 'desirable' that certain measures be taken. He stood corrected by the judgment of the Court in the LaGrand case $^{37}$ and had to concede defeat; yet he rarely missed an opportunity to reiterate, in his usual elegant way, that the Court had got it wrong. ${ }^{38}$

If we consider only these snippets of his scholarship, we could expect that Hugh would probably not have attracted a great deal of research funding; yet, what a great scholar he was! We remember that one of his proudest moments was obtaining his second Doctorate, an LLD from the University of Cambridge based on his accumulated writings in the field of international law. When the award was announced, he was 80 .

As an educator, he was certainly demanding (as he could also be as a supervisor at the Court!). Not only did he expect students to know already a great deal about international law, its sources and operating methods; he also had an inclination to use elaborate vocabulary, forgetting at times that many of his students (even those who were native English speakers) often required the Oxford English Dictionary to follow his class.

His approach to teaching international dispute settlement, and international law in general, very much reflected his scholarly approach. When giving a class, Hugh sought to transfer his impressive knowledge of the law and procedure of the International Court of Justice, insisting on the importance of fundamental questions, such as the existence and definition of a dispute, the notion of mootness and justiciability, and the functioning of the optional clause and incidental proceedings before the Court. He had a vast knowledge of the cases brought before the Court and remembered precisely why a judgment or order had been drafted in a certain way - and hence could, without much hesitation, explain what a certain paragraph of the Court's decision did or did not mean, taking care not to disclose any confidential information about the deliberations. He did, however, on occasion express doubts whether it was actually worth spending much time on the law and procedure of the Court, considering that the number of cases dealt with by the principal judicial organ of the United Nations amounts to a fraction only of the total number of decisions made by international courts and tribunals. But in the end, he could always be convinced that indeed it is necessary to cover, and explain to students, the general - and some would say technical - principles of international dispute settlement and international procedure as applied by the Court, to the extent that the law and practice of the Court was, and continues to be, of importance for most other courts and tribunals.

\footnotetext{
${ }^{36} \mathrm{H}$. Thirlway, 'The indication of provisional measures by the International Court of Justice', in R. Bernhardt, Interim Measures Indicated by International Courts (1994). The discussions reproduced in pages 119-52 show that he stood his ground against the opposition of most discussants.

${ }^{37}$ LaGrand (Germany v. United States of America), Judgment of 27 June 2001, [2001] ICJ Rep. 2001, at 466. It is worth noticing that the Court's judgment was rendered at a time when Hugh had interrupted his service at the Registry and had accepted the position at the Geneva Institute of Graduate Studies.

${ }^{38}$ E.g., H. Thirlway, Panel IV: 'International courts as lawmakers: Unacknowledged legislators: Some preliminary reflections on the limits of judicial lawmaking', in R. Wolfrum and I. Gätzschmann (eds.), International Dispute Settlement: Room for Innovations? (2013), at 311-23: 'There is however a special class of case in which a decision of the Court that could be regarded as incorrect would nevertheless have, de facto, virtually complete authority: if the decision concerned the Court's own legal powers. Here the decision in the LaGrand case as to the binding character of provisional measures may serve as a paradigm.', at 319 .
} 


\section{The Mensch}

Contrary to what his impressive list of publications might make us believe, he was no Fachidiot. Far from it: Hugh Thirlway was a man of many talents and interests. Most importantly, he was unconventional, something he did not display, but rather concealed behind the appearance of an exemplary civil servant and methodical legal scholar. Hugh was a non-conformist with a mildly mischievous sense of humour, ${ }^{39}$ while being a man of great distinction and elegance. As too few people are aware, he wrote poems, including on the case law of the Court, ${ }^{40}$ as a pastime, and was nominated 'ace limerician'. ${ }^{41} \mathrm{He}$ composed music, ${ }^{42}$ and played the piano to a high standard until his deafness made this an impossible exercise. He also was the proud holder of a pilot's licence and for a time, owned a Cessna plane. ${ }^{43}$ And, last but not least, he was the head of a large family. Idleness and contemplation were not part of Hugh's otherwise very rich vocabulary.

It is fair to say that he was one of those, nowadays rare, individuals who was able to be a stellar international lawyer and live the life of a polymath in ... The Hague! In contrast to many members of the expat community, he learned Dutch and made his way in Hague circles, mainly through musical activities, but also by simply being a friendly neighbour. It might have helped that he had a real interest in people, a distinct social fibre and did not forget about those less fortunate. When he had lost his ability to play music, he donated his beautiful grand piano to the Koninklijk Conservatorium in The Hague. As a last generous gesture, in his will, Hugh also donated his personal law library, containing more than 500 titles, to the International Law Book Facility, an organization that provides legal textbooks across the globe to non-profit organizations in need of legal research resources.

\footnotetext{
${ }^{39}$ Just an illustration of a piece he wrote, set to music long gone, for a Christmas party at the Lauterpacht Institute in 2001, which starts:

'When I consider how the law has developed since the days of Grotius,

I find its proliferation atrocious;

How much legal writing there is to be read through, with very little profit,

There's simply too much of it.

Of one thing I'm absolutely sure:

There is far too much international law!

${ }^{40} \mathrm{H}$. Thirlway, 'Dulce est Desipere in Loco', in U. Fastenrath et al. (eds.), From Bilateralism to Community Interest, Essays in Honour of Judge Bruno Simma (2011); H. Thirlway, 'Case Notes - A Collection of Trivia Accumulated over Many Years in the Service of the International Court of Justice', (2010) (unpublished - privately circulated).

${ }^{41}$ "Tinkering with spelling for humorous effect is optional, as in "Dracula" and "vernacula," as ace limerician Hugh Thirlway has done.', P. Myers, 'Get your 'rick rolling: Style Invitational limerick guide’, Washington Post, 8 August 2019, available at www.washingtonpost.com/lifestyle/style/get-your-rick-rolling-style-invitational-limerick-guide/2019/08/05/ad216cf8b7b0-11e9-b3b4-2bb69e8c4e39_story.html. As Ms. Myers from the 'Style Invitational' informed us, Hugh Thirlway contributed to the Washington Post weekly wordplay contest regularly for more than a decade, most recently in 2018 . His contributions were published 37 times! The limerick of the week referred to in the guide above had as instruction that it had to feature a word beginning with 'bl-'. Here is what Hugh sent to the Washington Post:
}

'When invited to dine with Count Dracula,

I expected a menu spectacula;

But d'you know what I got?

Merely blutwurst, that's what!

(I.e., "blood sausage" - that's the vernacula).' (2010)

${ }^{42}$ See, e.g., H. Thirlway, 'Partitions de la musique spécialement composée pour la cérémonie', in M. Bedjaoui and H. Thirlway, The International Court of Justice in Its Heyday: Le Bel Âge de la Cour internationale de Justice (1996).

${ }^{43} \mathrm{~A}$ planned flight with one of us, when Hugh was well into his seventies, never actually materialized, much to our relief: rumour had it that he once crashed his plane in some cornfield in South-East England. 


\section{Our Friend}

Our community has lost an international civil servant with the soul of a scholar, a scholar with the soul of an international civil servant. We have lost a mentor, a teacher, a friend, and are indebted to Hugh for all he has brought to us. We hope we will be able to carry on his 'critical' thinking in our respective fields of legal practice and scholarship, and that we will succeed in being freespirited international lawyers as he was. Many others in our small professional community spread around the world will feel the same way. Hugh Thirlway will forever remain nearby, in the wings of our stage. Farewell, Hugh, with gratitude. 